\title{
Penerapan Sistem Penilaian Sasaran Kinerja Pegawai (SKP) di Bagian Kesejahteraan Rakyat (Kesra) Kantor Pemerintah Kabupaten Bojonegoro
}

\author{
Wiwin Nur Karmilasari, Triesninda Pahlevi \\ Universitas Negeri Surabaya, Surabaya, Indonesia \\ Email authors: wiwin.17080314024@mhs.unesa.ac.id/triesnindapahlevi@unesa.ac.id
}

\begin{abstract}
ABSTRAK
Penelitian ini dilatarbelakangi dengan adanya peraturan mengenai penilaian kinerja negeri sipil, yaitu peraturan pemerintah No. 46 Th 2011 yang sudah lama diberlakukan di kantor Pemerintah Kabupaten (PEMKAB) Bojonegoro, Jawa Timur namun baru diberlakukan pada akhir tahun 2013. Tujuan penelitian inidilakukan karena untuk mengetahui bagaimana Proses penilaian SKP dengan adanya kendala yang ditemukan. di kantor Pemerintah Kabupaten Bojonegoro unit Kesejahteraan Rakyatdan menganalisis kelemahan. Sistem penilaian prestasi kerja saat ini berbeda dengan sistem SKP penilaian kinerja sebelumnya dengan sebutan nama DP3, pada SKP tersebut pegawai ikut terlibat aktif dalam menentukan rencana penilaian SKP dengan kurun waktu selama satu tahun kedepan, karena sistem penilaian ini dikatakan masih baru bagi para pegawai maka dibutuhkan penyesuaian dengan melakukan pembinaan, sosialisasi dan pendampingan dari bidang kepegawaian kantor Pemkab Bojonegoro.peneliti mencoba memberikan penjelasan tentang bagaimana penerapan sistem penilaian SKP di kantor pemkab Bojonegoro. Pada kantor tersebut ditemukan bahwa penerapan penilaian SKP sudah berjalan cukup objektif untuk aspek-aspek kualitatif, aspek kualitas dan aspek perilaku kerja, namun dirasa masih belum begitu objektif pada aspek waktu dan aspek biaya. Peneliti menggunakan metode penelitian kualitatif dengan pendekatan deskriptif.,dengan teknik pengambilan subyek dalam penelitian ini yaitu purposivesampling. peneliti menggunakan teknik pengumpulandata yaitu wawancara, observasi, dan dokumentasi. Pada pegawai Pemerintah Kabupaten (PEMKAB) Bojonegoro Jawa Timur yang didapat dari hasil penelitian adalahdalam penilaian SKP masih menerapkan proses penilaian secara manual, namun dalam pengisian menggunakan format dari BKKP Bojonegoro, untuk nilai SKP berdasarkan dari penilai dalam masing-masing kantor bidang. Tujuan dari penelitian ini adalah untuk mengetahui bagaimana Proses penilaian SKP dengan adanya kendala yang ditemukan. dalammenjamin objektivitas pembinaan Pegawai Negeri Sipil (PNS) dalam menerapkan sistem penilaian kinerja SKP masih dalam masa penyesuaian.DalamHasil penelitian menunjukkan bahwa terdapat kelemahan dalam menerapkan SKP antara lain: (1) belum seluruh pegawai PEMKAB menguasai Teknologi, kurangnya sumber daya manusia yang menangani SKP; (2) fasilitas teknologi kurang memadai; (3)kurang adanya ketegasan dalam penentuan batas waktu pengisian maupun pengumpulan dan uraian tugas jabatan untuk penelitian dan pengolah data PEMKAB Bojonegoro SKP Kurang sesuai dengan tugas mereka di Kantor.
\end{abstract}

Kata Kunci: Kelemahan Sistem Penilaian SKP,Proses Penilaian SKP, sistem Penilaian Manual.

\section{PENDAHULUAN}

Peneliti tertarik untuk meneliti dibagian kesra karena yang diketahui dari bagian kesra ini merupakan bagian yang paling banyak dalam penanganannya dari beberapa bagian lain, bagian ini yang menangani masalah sosial namun bukan badan sosial yang berdiri sendiri melainkan Organisasi atau subbagian yang menangani bantuan dana sosial/kemasyarakatan.Selain itu dalam penanganan dibagian Kesra ini sering terjadi kesalahan dan SDM belum maksimal dalam pekerjaan, serta kurangnya jumlah pegawai dalam menyelesaiakan tugas khususnya bagian penanganan beasiswa.

Sebelumnya untuk melakukan penilaian kinerja seseorang pegawai negeri sipil menggunakan sistem yang dulunya disebut sebagai Daftar Penilaian Pelaksanaan Perkerjaan Pegawai Negeri Sipil(DP3).(Syafri 2014)mengungkapkan pada kenyataannya DP3 PNS 
kurang efektif sebab sistem penilaian yang digunakan bersifat rahasia.Berbeda dengan sistem penilaian menggunakan SKP.

Menurut (Winarhadi 2013)dalam sebuah annual report Kementrian Pertanian 2013, menyebutkan bahwa SKP dapat menggambarkan kondisi yang sebenarnya, sebab dalam penilaian SKP ini lebih jelas, yang terdiri dari beberapa unsur diantaranya yaitu: penilaian kinerja, target dari sasaran kinerja pegawai, perilaku kerja dan penilaian capaian SKP. Dalam penerapan SKPdi Kantor Pemerintah Kabupaten Bojonegoro sudah menggunakan web, atau Aplikasi bernama Sistem Manajemen ASN Bojonegoro (SIMASBRO) dengan alamathttp://simabro.bojonegorokab.go.id.dan diberlakukan sejak Agustus 2020 lalu. Sedangkan proses penilaian SKP dilakukan secara manual oleh staff Subbag Keagamaan dari organisasi unit bagian Kesejahteraan Rakyat (Kesra). Selain kendala tersebut ada kalanya kendala lain, diantaranya yaitu: 1) belum seluruh pegawai Pemkab menguasai teknologi, minimnya sumber daya manusia yang menangani SKP di Kantor Pemkab Bojonegoro, 2) teknologi yang belum memadai, 3) belum adanya ketegasan dalam melaksanakan pengisian maupun pengumplan hasil pengolahan data dan hasil penelitian di kantor pemkab Bojonegoro. Dari hal ini peniaian kinerja pegawai belum sesuai dengan tugas mereka

Oleh karena itu tujuan penelitian ini yakni untuk mengetahui bagaimana Proses penilaian SKP terhadapkendala yang ditemukan dalam pengisian SKP secara manual di kantor Pemerintah Kabupaten Bojonegoro dalam menjamin objektivitas kinerja Pegawai Negeri Sipil (PNS).

\section{Kinerja}

Dalam organisasi atau institusi publik, sebagai ASN yang notabene melayani masyarakat, salah satu indikator yang perlu diukur untuk mengetahui pelayanan yang diberikan pada masyarakat, stakeholder yang lain adalah dengan melakukan pengukuran kinerja. Selain itu, kinerja dapat digunakan sebagai medium untuk mengukur ASN terkait dengan kenaikan jabatan, dan sebagainya. Kinerja merupakan prestasi dari pegawai yang dapat dilihat stadart atau kemampuan kerjanya.

(Hazrati 2017:2)berpendapat bahwa "Kinerja merupakan gambaran mengenai tingkat kemampuan pencapaian pelaksanaan suatu kegiatan/program/kebijakan dalam kurun waktu tertentu berdasarkan tujuan dan sasaran yang telah ditentukan guna mewujudkan visi dan misi organisasi.Sehingga dapat diambil kesimpulan bahwa kinerja merupakan gambaran kemampuan seorang individu dalam menuntaskan pekerjaan yang diberikan kepada institusi sesuai dengan job desk-nya.

\section{Penilaian Prestasi Kerja}

Sebuah organisasi publik dapat membuat sebuah kebijakan internal melalui penilaian kinerja pegawai atau karyawannya untuk dijadikan sebuah reward yang berupa prestasi kerja pegawai atau karyawan dalam kurun waktu tertentu. Menurut (Setiyobudi 2017:3) bahwa "Penilaian Kinerja atau Performance Appraisal (PA) adalah sebuah sistem yang formal digunakan dalam beberapa periode waktu tertentu untuk menilai prestasi kerja seorang karyawan".

Berdasarkan definisi menurut para ahli dapat ditarik disimpulkan bahwa penilaian prestasi kerja menjadi hal penting bagi organisasi publik. Penilaian prestasi kerja dilakukan secara berkala sesuai dengan kebutuhan masing-masing instansi ataupun organisasi. Penilaian kinerja, pada umumnya dilakukan oleh pimpinan instansi atau organisasi dalam mengetahui kinerja yang sudah dicapai pegawai maupun karyawannya sewaktu melakukan aktivitas dalam bidang yang ditugaskan pada suatu lembaga atau organisasi. 


\section{Penilaian Sasaran Kinerja Pegawai (SKP)}

Setiap organisasi publik, terutama yang melakukan pelayanan terhadap masyarakat. Penilaian Kinerja menjadi penting, untuk itu setiap Satuan Unit Kerja di tingkat Pemerintah mulai menggunakan penilaian kinerja dengan menggunakan SKP. SKP adalah Sasaran Kerja Pegawai yang ada dalam salah satu unsur Penilaian Prestasi Kerja PNS yang diatur dalam Peraturan Pemerintah Nomor 46 Tahun 2011(Hazrati 2017:4). Dengan SKP rencana kerja dan indikator kinerja harus benar-benar mampu di capai dan di ukur oleh pegawai mengenai apa yang menjadi tujuan organisasi dalam waktu satu tahun dapat di ketahui dari sistem penilaian SKP tersebut.

Sebagian cara evaluasi terhadap kinerja dalam waktu tertentu bertujuan untukmengetahui sejauh apa prestasi kerja dalam menjamin objektivitas pembinaan PNS yang dilakukan berdasarkan sistem yang telah digunakan. (Zuardhi 2014)pada sosialisasi SKP yang dilakukan di lingkungan Kementrian mengatakan bahwa dalam melakukan kebijakan prestasi kerja, instansi menggunakan indikator yang ada pada penilaian SKP yakni objektifitas, terukur, aktual, transparan dan partisipan.

\section{METODE PENELITIAN}

Dalam penelitian ini, peneliti menggunakan metode penelitian kualitatif yang merupakan sebuah metode untuk mengeksplorasi dan mendalami makna yang diperoleh melalui beberapa personal ataupun sekelompok individu yang dianggap memiliki permasalahan sosial. (Creswell, 2017)mengemukakan bahwa proses penelitian kualitatif ini melibatkan upaya-upaya penting, seperti mengajukan pertanyaan-pertanyaan dan prosedur-prosedur, mengumpulkan data yang spesifik dari para partisipan, menganalisis data secara induktif mulai dari tema-tema khusus ke tema-tema umum, dan menafsirkan makna data.

Pada objek penelitian ini adalah penerapan dan kelemahan pada sistem penilaian SKP Tujuan dari penelitian kualitatif ini adalah mengetahui gambaran dan penjelasan yang nyata dari peristiwa secara rinci, sempurna dan berakhir. Penelitian ini bertempat di Kantor Pemerintah Kabupaten Bojonegoro, dengan teknik pengambilan subyek dalam penelitian ini yaitu purposivesampling. Purposive sampling yaitu dimana cara/teknik untuk menentukan penentuan suatu sampel atau specimen dalam mempertimbangkan suatu hal dalam melakukan suatu penelitian dengan menggunakan teknik purposivesampling(Sugiyono 2016:85).

Teknik pengumpulan data didapat dari data pokok dan data tambahan. Data /pokok diperoleh dari hasil wawancara dan observasi, sedangkan data tambahan diperoleh melalui peraturan dan perundang-undangan terkait dengan penilaian kinerja pegawai serta informasi yang relevan terhadap permasalahan yang diteliti. Dalam hal ini menggunakan tiga teknik pengumpulan data seperti yang dikemukakan oleh (Sudaryono. 2016)sebagai berikut: 1) Observasi, teknik informasi yang dipakai untuk memahami data dari sumber fenomena/peristiwa, dan tempat.

Selanjutnya peneliti dalammelakukan keabsahan data menggunakan teknik triangulasi. Pada tahap triangulasi yaitu terdapat triangulasi sumber, triangulasi teknik pengumpulan data, dan waktu (Sudaryono 2016).

\section{HASIL DAN PEMBAHASAN}

\section{Penerapan SKP di Bagian Kesra Pemkab Bojonegoro}

Dari hasil penelitian SKP data yang diperlukan yakni identitas PNS yang berkaitan dengan laporan, SK, naskah, dan dokumen lainnya yang akan dimonitoring oleh pimpinan.. 
Disamping itu, jika hal tersebut akan diubah menjadi kebijakan, tentu akan berdampak juga pada indikator penilaian prestasi kerja yang dilakukan melalui SKP, yakni objektifitas, terukur, aktual, transparan dan partisipan. Meski salah satu unsur, partisipan, misalnya telah dilakukan di Kesra Pemkab Bojonegoro.

\section{Proses pengisian SKP manual}

Berdasarkan dari hasil obsevasi di lapangan Tata Cara Pelaporan evalusi prestasi kerjapegawai, diantaranya yaitu :

1) BKKP menyediakan template yang dibagikan (sharing template) kepada OPD yang berisikan PNS ID, NIP, Nama dan NIP Atasan Pejabat Penilai, Nama dan NIP Pejabat Penilai beserta nilai SKP dan perilaku (template dapat diunduh pada link berikut) http://s.id/Template_SKP

2) OPD mengisikan template rekon SKP sesuai dengan kolom/field yang tersedia.

3) Template rekon SKP yang telah diisikan oleh OPD dikirim kembali ke BKKP untuk diolah dan diupload ke SAPK

4) Dimohon untuk tidak merubah format template yang telah disediakan.

5) Form template tidak perlu dicetak/di print. Kelemahan sistem penilaian SKP.



Kelemahan merupakan suatu hal yang negatif dan membutuhkan sebuah solusi untuk mengatasinya.Berdasarkan hasil observasi dilapangan dalam proses pengisian Sasaran Kinerja Pegawai (SKP) terdapat beberapa kendala yang ditemukan, antara lain: 1) kurangnya fasilitas yang memadai dalam pengisian SKP tersebut, 2)belum seluruh pegawai PEMKAB menguasai Teknologi, 3)sangat minimnya sumber daya manusia yang mengampu terkait dengan SKP, 4) belum adanya ketegasan dalam penentuan batas waktu pengisian maupun pengumpulan, 5) uaraian tugas jabatan untuk penelitian dan pengolah data PEMKAB Bojonegoro SKP belum selaras dengan tugas mereka dikantor, 6)seringnya kehilangan dokumen yang berupa paper dalam penyimpanannya.7) kinerja pengisian pegawai tidak sesuai dengan tugas ataupun jabatannya. 


\section{Analisis kendala penerapan SKP di Kabupaten Bojonegoro}

Evaluasi prestasi kerja bersumber pada parameter SKP yang terdapat belum efisien, oleh sebab itu didalam riset ini hendak meningkatkan parameter SKP yakni inventivitas serta inovasi dalam melakukan tugas sera bertanggungjawab dan membuat saran strategi yang bisa membagikan masukan buat evaluasi prestasi kerja jadii lebih cocok dengan yang dicapai dan upaya kenaikan produktivitas oleh tiap pegawai. (Lutfiani, Maulita., Maarif, Mohamad Syamsul., dan Purnawarman 2019).

Menurut staff pengisian nilai SKP Dalam melaksanakan penilaian SKP di kantor Pemkab Bojonegorosudah sesuai dengan prosedurnya, dalam hal inisesuai dengan peraturan yang diberlakukan berdasarkan dari Badan Kepegawaian, Pendidikan dan Pelatihan (BKKP) Bojonegoro, Sedangkan untuk pengisian SKP belum sesuai karena dalam pengisian SKP bukan dari Bidang kepegawaian sendiri, melainan dari pegawai masing-masing bidang di kantor Pemkab.

Dalam penilaian Sasaran Kinerja Pegawai (SKP) dikantor Pemerintah Kabupaten Bojonegoro Bagian Kesra masih menerapkan sistem yang manual/belum tersistem, tentunya masih ada beberapakendala yang ditemukan, misalnya,(1)belum seluruh pegawai PEMKAB menguasai Teknologi, minimnya karyawan yang mengurus Penilaian kinerja pegawai; (2) teknologi yangbelum memadai; (3) masih menunda waktu dan tidak menargetkan dalam menentukan pengumpulan melalui Web Simasbro serta ekplanasi tugas jabatan dalam meneliti serta mengolah data di Pemkab Bojonegoro SKP belum selaras terkait hasil capaian dengan kewajiban para pegawai di kantor.

Dari beberapa kendala tersebut dapat ditemukan solusi yaitu Diberlakukan pembimbingan pada kinerja dalam melakukan penilaian dan pengisian Sasaran Kinerja Pegawai (SKP) yang mengarah pada sistem penilaian dan pengisian secara tersistem/online, dengan tujuan dapat mempermudah kinerja dalam melakukan dan menyelesaiakan tugas tersebut.

\section{KESIMPULAN}

Berdasarakan pandangan peneliti serta pengkajian, bahwa peneliti menanggapi hingga evaluasi prestasi kinerja karyawan atas dasar SKP saat ini masih menerapkan sistem yang manual, dalam penilaian Sasaran Kinerja Pegawai (SKP) di kantor Pemerintah Kabupaten Bojonegoro (PEMKAB) masih ditemukan beberapa kendala seperti (1) belum seluruh pegawai Kesra Pemkab Bojonegoro menguasai teknologi; (2)minimnya keahlian karyawan yang mengurus; (3) teknologi belum memadai; (4)masih menunda waktu dan tidak menargetkan dalam menentukan pengumpulan melalui Web Simasbro serta ekplanasi tugas jabatan dalam meneliti serta mengolah data di Pemkab Bojonegoro. (5) SKP belum selaras terkait hasil capaian dengan kewajiban para pegawai di kantor. Dalam proses pengisisan SKP dengan menggunakan format yang sudah diberikan dari Badan Kepegawaian, Kependidikan dan Pelatihan (BKKP), namun nilaiSKPberdasarkan dari kantor bidang masing-masing yang menilai.

SKP dapat memberikan penilaian yang efektif dan lebih akurat dibandingkan dengan DP3.Untuk meminimalisir kendalapenerapan SKP yang tersistem, maka pimpinan secara berkala menyusun rencana dan strategi sehingga penilaian dapat berjalan secara efektif di Pemkab Bojonegoro.

Penelitian hanya hanya terbatas pada analisis penerapan sistem penilaian di Kantor Pemerintah Kabupaten Bojonegoro, tidak menganalisis secara menyuluruh pada kantor Pemerintah Kabupaten Bojonegoro unit satuan kerja, salah satunya yakni Bagian Kesejahteraan Rakyat Pemerintah Kabupaten Bojonegoro atau yang lebih dikenal dengan 
sebutan Kesra. Fokus penelitian berikutnya adalah di kantor Pemkab Bojonegoro yang melaksanakan penilaian SKP.

Dari hasil penelitian dankajian di atas, bahwa penulis membagikan saran yaitu, dari penelitian ini hendaklan disempurnakan dengan melakukan penelitian lebih lanjur mengenai dampak penilaian SKP terhadap kinerja pegawai di Pemerintah Kabupaten Bojonegoro unit Bagian Kesra. Dengan melakukan penelitian secara mendalam terkait dengan sistem penilaian SKP yang menyeluruh di Kantor Bagian Kesra sehingga bahan penelitian tersebut dapat digunakan sebagai bahan evaluasi pimpinan untuk meningkatkan kinerja pegawai di lingkungan Kesra Pemkab Bojonegoro.Karena pegawai menganjurkan belum memahamiprosesmengoperasikan teknik untuk menilai kinerja yang diperlukan dan tersistem pada penilaian kinerja ini, maka seharusnya pemerintah atau instansi yang bersangkutan memberikan pelatihan dan pengetahuan terhadap tata cara pengisian Penilaian Kinerja SKP dengan cara tersistem/online kepada seluruh pegawai instansi agar pegawai lebih mengerti dan sadar akan pentingnya penilaian kinerja ini. Sehingga akan lebih fektif dan akurat dalam melakukan penilaian menggunakan e-SKP, serta lebih memudahkan penilaian dalam melakukan penilaian kinerja pegawai PNS.

\section{DAFTAR PUSTAKA}

Anshori, Z., Kelana, M. Y. I., Sulaeman, M. M., \& Utami, A. T. (2020). PKM: Pelatihan Penerapan Sistem Informasi Akuntansi Dalam efektivitas Pelaksanaan Pengendalian Intern Penjualan (Studi Kasus Pada CV. Gading Kuning Lamongan). TRIDARMA: Pengabdian Kepada Masyarakat (PkM), 3(1, Mei), 46-49.

Creswell, J. W. 2017. Research Design, Qualitative, Quantitative, and Mixed Methods Approaches.

Gani, Bina Danny R. 2018. "Penerapan Sistem Penilaian Prestasi Kerja Pegawai Negeri Sipil Di Kantor Regional Iii Badan Kepegawaian Negara." Asy-Syari'ah 20(1):85-96. doi: 10.15575/as.v20i1.2997.

Hartanto, Shanti. 2016. "PENERAPAN SISTEM PENILAIAN SASARAN KERJA PEGAWAI (SKP) DALAM RANGKA PENINGKATAN KINERJA PEGAWAI NEGERI SIPIL (PNS)DI BALAI PELESTARIAN NILAI BUDAYA JAWA BARAT." Ilmiah 634.

Hazrati, Khairina. 2017. "Peran Sasaran Kinerja Pegawai (Skp) Dan Sertifikasi Terhadap Kinerja Pustakawan Khairina Hazrati." Iqra 11(02):17-33.

Ikawati, Destiyana. 2017. "Penilaian Prestasi Kerja Melalui Sasaran Kerja Pegawai Pada Badan Kepegawaian Daerah Kota Yogyakarta.” Jurnal Ilmiah 1:1-11.

Ivaramulya, Elfri Annisa, and Jazimatul Husna. 2018. "Analisis Kinerja Pegawai Kearsipan Dalam Mengelola Arsip Dinamis Inaktif Di Dinas Arsip Dan Perpustakaan Kabupaten Purworejo." Jurnal Ilmu Perpustakaan 7(1):211-20.

Kadir, Abdul. 2018. "Evaluasi Kinerja Pegawai Bagian Program Kemitraan Dan Bina Lingkungan Pada PT. Perkebunan Nusantara III (Persero) Medan." Jupiis: Jurnal Pendidikan Ilmu-Ilmu Sosial 10(2):205. doi: 10.24114/jupiis.v10i2.11386.

Lutfiani, Maulita., Maarif, Mohamad Syamsul., dan Purnawarman, Trioso. 2019. "Analisis Pendukung Keputusan Penilaian Prestasi Kerja Tenaga Kependidikan.” Jurnal Ilmiah Manajemen 1(1):19-35.

Pambudy, A. P., \& Syairozi, M. I. (2019). Analisis Peran Belanja Modal dan Investasi Swasta Terhadap Pertumbuhan Ekonomi Serta Dampaknya Pada Kesejahteraan Masyarakat. Jurnal Ekonomi dan Bisnis, 20(1), 26-39. 
Setiyobudi, Eko. 2017. "Analisis Sistem Penilaian Kinerja Karyawan Studi Pada PT. Tridharma Kencana." JABE (Journal of Applied Business and Economic) 3(3):170. doi: 10.30998/jabe.v3i3.1768.

Sudaryono. 2016. Metode Penelitian Pendidikan.

Sugiyono, Prof. Dr. 2016. Metode Penelitian Kuantitatif, Kualitatif, Dan R\&D. Bandung: ALFABETA.

Syafri, Wirman. 2014. Manajemen Sumber Daya Manusia Dalam Organisasi Publik.

Syairozi, M. I. (2021). Analisis Kemiskinan di Sektor Pertanian (Studi Kasus Komoditas Padi di Kabupaten Malang). Media Ekonomi, 28(2), 113-128.

Winarhadi, Mohammad. 2013. "Laporan Capaian Kinerja Biro Organisasi Dan Kepegawaian 2013."

Zuardhi, Trisno. 2014. Biro Kepegawaian Kemendikbud Sosialisasi SKP. 